\title{
Reducing Primary Care Attendance Intentions for Pediatric Respiratory Tract Infections
}

Annegret Schneider, Dipl-Psych, $\mathrm{PhD}^{1,2}$

Christie Cabral, MRes, $\mathrm{PbD}^{3}$

Natalie Herd, $\mathrm{PbD}^{1,2}$

Alastair Hay, FRCGP $P^{2,3}$

Joanna May Kesten, $\mathrm{PbD}^{2,3,4}$

Emma Anderson, MSc,

DHealthPsych ${ }^{2,3}$

Isabel Lane, MRes, MRCGP

Charles Beck, $M P H, P b D^{5}$

Susan Michie, DPbil ${ }^{1,2}$

'University College London, London, United Kingdom

${ }^{2}$ NIHR Health Protection Research Unit in Evaluation of Interventions, Bristol, United Kingdom

${ }^{3}$ University of Bristol, Bristol, United Kingdom

${ }^{4}$ NIHR Collaboration for Leadership in Applied Health Research and Care West, Bristol, United Kingdom

${ }^{5}$ Public Health England, Bristol, United Kingdom

\section{in MORE ONLINE www.annfammed.org}

Conflicts of interest: authors report none.

\section{CORRESPONDING AUTHOR}

Annegret Schneider, MSc, PhD

Room 504 Alexandra House

17-19 Queen Square

London, WC1N 3AZ

a.schneider@ucl.ac.uk

\begin{abstract}
PURPOSE The aim of this study was to evaluate a theory and evidence-based, parent-targeted online intervention, combining microbiological local syndromic surveillance data, symptom information, and home-care advice, to reduce primary care attendance for self-limiting, low-risk pediatric respiratory tract infections (RTIs).
\end{abstract}

METHODS The effect of this novel intervention on primary care attendance intentions was evaluated in an online experimental study. A representative sample of mothers $(n=806)$ was randomly assigned to receive the intervention material before (intervention) or after (control) answering questions concerning attendance intentions for an RTI illness scenario and mediating factors. Both groups provided feedback on the material. Group comparisons, linear regression, and path analyses were conducted.

RESULTS Intervention participants reported lower attendance intentions compared with control participants ( $d=0.69,95 \% \mathrm{Cl}, 0.55-0.83)$, an effect that remained when controlling for demographic and clinical characteristics $(\mathrm{B}=-1.62,95 \% \mathrm{Cl},-1.97$ to -1.30$)$. The path model highlighted that the intervention effect $(B=-0.33,95 \% \mathrm{Cl},-0.40$ to -0.26$)$ was mostly indirect and mediated by infection and antibiotic knowledge, symptom severity concerns, and social norm perceptions concerning attendance. Information on when to attend was rated as the most important intervention component 227 times, followed by symptoms rated 186 times. Information on circulating viruses was rated as least important 274 times.

CONCLUSIONS The intervention was effective in reducing primary care attendance intentions by increasing knowledge, lowering attendance motivation, and reducing the need for additional resources. The contribution of individual intervention components and effects on behavioral outcomes requires further testing.

Ann Fam Med 2019;17:239-249. https://doi.org/10.1370/afm.2392.

\section{INTRODUCTION}

$\mathrm{R}$ espiratory tract infections (RTIs) are one of the main reasons for primary care consultation for children. ${ }^{1}$ These consultations contribute to primary care clinicians' increasing workload and cost the National Health Service $£ 31.5 \mathrm{M}$ per year. ${ }^{2,3}$ Primary care consultations for RTIs often lead to unnecessary antibiotic prescribing, ${ }^{4,5}$ promoting antimicrobial resistance. ${ }^{6-9}$ Providing parents with actionable information can reduce the number of unnecessary consultations by up to $40 \%,{ }^{10}$ can have a significant positive impact on resources, and can promote antimicrobial stewardship. ${ }^{11,12}$

When children have an RTI, parents want to know how to manage symptoms at home and which symptoms require medical attention. ${ }^{13}$ Consulting for a child with an RTI is perceived to be the safest course of action, and to be the socially acceptable norm if parents have any doubt about a medical threat to their child. ${ }^{14}$ Qualitative research investigating the value of an intervention combining real-time community-level information on locally prevalent RTIs with information about typical symptoms 
and duration found, that while most parents thought such an intervention was useful, and they anticipated using the information to inform lay diagnoses, they had mixed views about whether it would influence decisions to consult primary care physicians. ${ }^{15}$

The current research is an experimental evaluation of a novel online intervention informed by prior research, following recommendations for evaluating complex digital behavior change interventions. ${ }^{16,17}$ This study aimed to investigate the effect of the intervention on primary care attendance intentions and mediating factors, and parents' perception of the intervention material.

\section{METHODS}

\section{Intervention Description}

The intervention was developed based on a behavioral analysis of the target behavior: consulting with a primary care health professional. Using the capability, opportunity, motivation-behavior model, ${ }^{18}$ potential pathways of influence were identified as the basis to develop the intervention and to predict mechanisms of action. The intervention (Figure 1 and Supplemental Appendix 1, available at http://www.AnnFamMed.org/ content/17/3/239/suppl/DC1/) was designed to change parents' capability, opportunity, and motivation to consult primary care for low-risk, self-limiting RTIs in children, by providing microbiological locally enhanced syndromic surveillance data, symptom duration information, and home-care advice. The following behavior change techniques ${ }^{19}$ were used in the intervention: providing information, instructions on how to perform home-care behaviors, encouraging social comparison, and referring to credible information sources.

Information included in the intervention was drawn from official influenza statistics, ${ }^{20}$ the Caring for Children With Cough website, ${ }^{21}$ and national guidance. $^{22,23}$ To increase relevance, comprehension, and recall, the intervention contained information tailored to parents as a target group, repeated key points, categorized information in a structured way, kept instructions brief, simple, and specific, and used supporting visualizations. ${ }^{24-27}$ To receive feedback from the target group, ${ }^{28}$ a parent advisory group was involved in development of the intervention (Supplemental Appendix 2, available at http://www.AnnFamMed.org/ content/17/3/239/suppl/DC1/).

\section{Study Design and Procedure}

The study used an experimental design that randomly allocated participants, in equal numbers, to the inter-

Figure 1. Standardized estimates for the adjusted intervention path model.

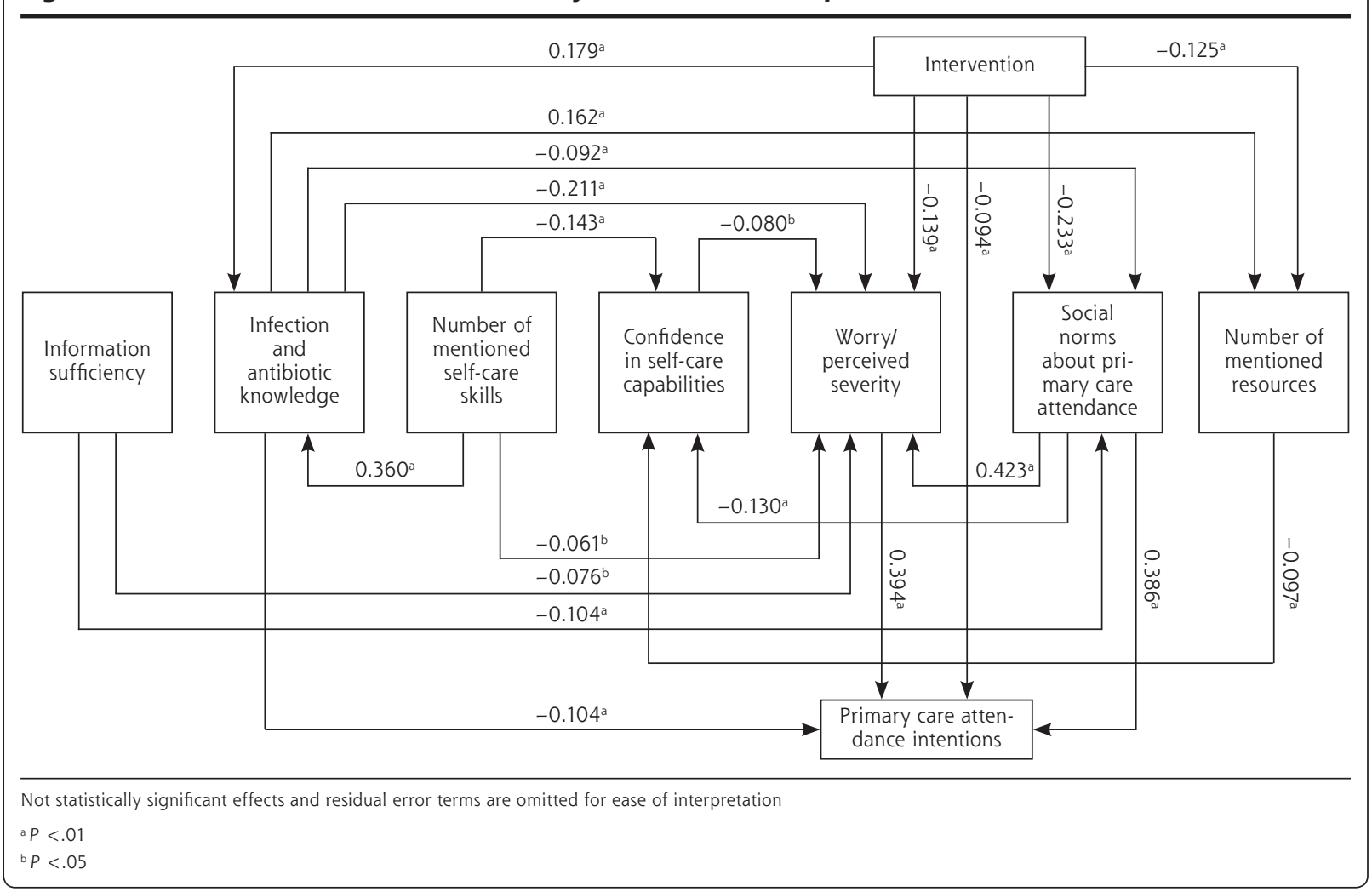


vention or control group. Research participants viewed the intervention and completed the survey online. They accessed the survey remotely via a hyperlink and they were automatically randomized based on computergenerated sequences (Supplemental Appendix 4, available at http://www.AnnFamMed.org/content/17/3/239/ suppl/DC1/). Following a scenario approach adopted by Godinho et $\mathrm{al}^{29}$ and McGlone et $\mathrm{al}_{1}{ }^{30}$ participants were asked to imagine that their youngest child was experiencing symptoms consistent with a rhinovirus infection (Supplemental Appendix 3 available at http://www. AnnFamMed.org/content/17/3/239/suppl/DC1/). The intervention group was presented with the intervention material in a series of static images (Supplemental Appendix 1) before answering questions concerning primary care attendance intentions and factors influenc- ing their decision (Table 1). ${ }^{29,31-44}$ Control participants completed the same questions before being shown the intervention material. All participants provided feedback on the material, demographic information (child age and sex; parent age, employment, education, and ethnicity; and number of children), and clinical characteristics (pediatric primary care visits over the past 12 months, chronic health issues of the child) potentially associated with primary care attendance. ${ }^{21}$ Participants were asked to view the intervention material as they would if their child was suffering the described illness to simulate real-life usage instead of examining all information in-depth. Scales, used to assess psychological processes involved in behavior change according to the capability, opportunity, motivation-behavior model, ${ }^{18}$ and feedback on the intervention material were based

Table 1. Details of Survey Used to Assess the Target Constructs in Order of Appearance

\begin{tabular}{|c|c|c|c|}
\hline Target Construct/Scale ${ }^{a}$ & Items & $\begin{array}{l}\text { Answer } \\
\text { Format }\end{array}$ & $\begin{array}{l}\text { Reliability } \\
\text { (Cronbach's } \alpha)\end{array}$ \\
\hline \multicolumn{4}{|l|}{ Main outcome } \\
\hline $\begin{array}{l}\text { Intentions-primary care } \\
\text { attendance intentions }{ }^{29,31-35}\end{array}$ & I want to visit a GP today/l intend to visit a GP today. ${ }^{b}$ & 5-point scale & 0.94 \\
\hline \multicolumn{4}{|l|}{ Potential mediating factors } \\
\hline $\begin{array}{l}\text { Social influence-social } \\
\text { norms about primary care } \\
\text { attendance } 31,32,35\end{array}$ & $\begin{array}{l}\text { People around me think I need to visit a GP today/approve of me } \\
\text { visiting a GP today/think I do not need to visit a GP today. }{ }^{b}\end{array}$ & 5-point scale & 0.81 \\
\hline $\begin{array}{l}\text { Emotions-worry/perceived } \\
\text { severity of a health threat }{ }^{36}\end{array}$ & $\begin{array}{l}\text { Would you say that your child's symptoms, as described in the } \\
\text { illness scenario, suggest that the illness is severe/serious/signifi- } \\
\text { cant/worrying/normal (given where I live and time of year)? }\end{array}$ & 5-point scale & 0.84 \\
\hline \multirow[t]{3}{*}{$\begin{array}{l}\text { Knowledge-information } \\
\text { sufficiency }{ }^{37,38}\end{array}$} & $\begin{array}{l}\text { How much do you think you currently know about the illness as } \\
\text { described in the scenario? }\end{array}$ & Scale of 0 to 100 & $\ldots$ \\
\hline & $\begin{array}{l}\text { How much knowledge would you need to adequately care for } \\
\text { your child showing the described symptoms? You might feel you } \\
\text { need the same/more/less, information about the topic. }\end{array}$ & Scale of 0 to 100 & $\ldots$ \\
\hline & $\begin{array}{l}\text { What additional information would you need to adequately care } \\
\text { for your child showing the described symptoms? Please describe. }\end{array}$ & $\begin{array}{l}\text { Open-ended } \\
\text { question }\end{array}$ & $\cdots$ \\
\hline \multirow{3}{*}{$\begin{array}{l}\text { Knowledge/skills/resources- } \\
\text { viral illness knowledge and } \\
\text { home-care } \text { test }^{29}\end{array}$} & $\begin{array}{l}\text { Thinking about the illness scenario, do you think the cause of your } \\
\text { child's symptoms is a viral infection/bacterial infection? }\end{array}$ & $\begin{array}{l}\text { True/False/ } \\
\text { I don't know }\end{array}$ & $\ldots$ \\
\hline & $\begin{array}{l}\text { Approximately how long do you think the symptoms of illness } \\
\text { (fever/high temperature/sore throat/cough) in your child could } \\
\text { last, from start to finish without any antibiotics? }\end{array}$ & Estimation in days & $\ldots$ \\
\hline & $\begin{array}{l}\text { How would you care for your child at home? Strategies and fur- } \\
\text { ther resources? }\end{array}$ & $\begin{array}{l}\text { Open-ended } \\
\text { question }\end{array}$ & $\cdots$ \\
\hline $\begin{array}{l}\text { Reflective motivation- } \\
\text { beliefs about home-care } \\
\text { capabilities }^{39}\end{array}$ & $\begin{array}{l}\text { When my child shows the symptoms described in the scenario, } \\
\text { I feel confident about looking after them at home/taking their } \\
\text { temperature/seeing if they need more fluids/checking for a rash/ } \\
\text { seeking advice from online resources/seeking advice or help } \\
\text { from family and friends/seeking advice or help from health care } \\
\text { professionals. }\end{array}$ & 5-point scale & 0.81 \\
\hline \multirow[t]{5}{*}{$\begin{array}{l}\text { Knowledge/beliefs-antibiotic } \\
\text { use }^{40-42}\end{array}$} & $\begin{array}{l}\text { Are most cold, cough, and flu illnesses caused by bacteria or } \\
\text { viruses? }\end{array}$ & Multiple choice & $\ldots$ \\
\hline & $\begin{array}{l}\text { Are antibiotics helpful in treating bacterial infections, viral infec- } \\
\text { tion, or both? }\end{array}$ & Multiple choice & $\ldots$ \\
\hline & $\begin{array}{l}\text { How often are antibiotics needed for cough or bronchitis/sore } \\
\text { throat/fever/earache/tiredness and aching/vomiting? }\end{array}$ & 5-point scale & $\ldots$ \\
\hline & $\begin{array}{l}\text { If my child does not receive an antibiotic for cold, cough, and flu } \\
\text { symptoms, they will be sick for a longer time. }\end{array}$ & 5-point scale & $\ldots$ \\
\hline & & & continues \\
\hline \multicolumn{4}{|l|}{$\mathrm{GP}=$ general practitioner. } \\
\hline \multicolumn{4}{|c|}{$\begin{array}{l}\text { a References to measures survey scales were based on. } \\
\text { b Reverse coded item. }\end{array}$} \\
\hline
\end{tabular}


Table 1. Details of Survey Used to Assess the Target Constructs in Order of Appearance (continued)

\begin{tabular}{|c|c|c|c|}
\hline Target Construct/Scale ${ }^{a}$ & Items & $\begin{array}{l}\text { Answer } \\
\text { Format }\end{array}$ & $\begin{array}{l}\text { Reliability } \\
\text { (Cronbach's } \alpha)\end{array}$ \\
\hline \multicolumn{4}{|l|}{$\begin{array}{l}\text { Intervention material } \\
\text { feedback }\end{array}$} \\
\hline \multirow[t]{5}{*}{ Clarity ${ }^{43}$} & Not at all understandable/very understandable & 7-point scale & 0.93 \\
\hline & Not at all comprehensible/very comprehensible & & \\
\hline & Does not make sense/makes sense & & \\
\hline & Confusing arguments/clear arguments & & \\
\hline & Unclear information presented/clear information presented & & \\
\hline \multirow[t]{3}{*}{ Credibility $4^{43}$} & Credible information presented/information presented not credible ${ }^{b}$ & 7-point scale & 0.85 \\
\hline & Valid claims/invalid claims ${ }^{b}$ & & \\
\hline & $\begin{array}{l}\text { Presented accurate information/did not present accurate } \\
\text { information }^{b}\end{array}$ & & \\
\hline \multirow[t]{5}{*}{ Cognitive challenge ${ }^{43}$} & Not intellectually stimulating/intellectually stimulating & 7-point scale & 0.70 \\
\hline & Not intellectually engaging/intellectually engaging & & \\
\hline & Would make people think/would not make people think ${ }^{b}$ & & \\
\hline & Not at all thought-provoking/thought-provoking & & \\
\hline & Did not really make me think/really made me think & & \\
\hline \multirow[t]{7}{*}{ Emotional arousal ${ }^{44}$} & Powerful impact/weak impact ${ }^{\mathrm{b}}$ & 7-point scale & 0.87 \\
\hline & Emotional/unemotional ${ }^{b}$ & & \\
\hline & Involving/uninvolving ${ }^{\mathrm{b}}$ & & \\
\hline & Boring/exciting & & \\
\hline & Arousing/not arousing ${ }^{b}$ & & \\
\hline & Stimulating/not stimulating ${ }^{b}$ & & \\
\hline & Strong visuals/weak visuals ${ }^{b}$ & & \\
\hline \multirow[t]{3}{*}{ Novelty ${ }^{44}$} & Unique/common ${ }^{b}$ & 7-point scale & 0.72 \\
\hline & Novel/ordinary ${ }^{b}$ & & \\
\hline & Unusual/usual ${ }^{b}$ & & \\
\hline \multicolumn{4}{|l|}{$\mathrm{GP}=$ general practitioner } \\
\hline \multicolumn{4}{|c|}{$\begin{array}{l}\text { a References to measures survey scales were based on. } \\
\text { b Reverse coded item. }\end{array}$} \\
\hline
\end{tabular}

on previous research and validated scales (Table 1, and Supplemental Appendix 3). Details of how the survey was amended to increase validity following testing with a parent advisory group are presented elsewhere (Supplemental Appendix 2). The survey required an average reading level (Flesch Reading Ease $=60$, Flesch-Kincaid Formula $=7.7$, Fog Index =9.7, SMOG Grading = 7.6). ${ }^{45}$ Ethical approval was obtained from University College London's research ethics committee (Project ID Number: CEHP/2013/508). The study protocol is available on the Open Science framework. ${ }^{46}$

\section{Participant Recruitment}

A representative sample, by age, socioeconomic status, and geographic location, of mothers living in England was recruited from January 24 through February 9, 2017 by a market research company online panel using a quota sample. The quota targets were relevant for mothers aged 18 to 65 years, and based on source data used for UK population studies, including participants until all quotas were filled (Supplemental Appendix 4). Participants did not receive financial compensation but they were offered points by the market research company, which can be accrued over time and redeemed for vouchers or for entering prize drawings. To maximize statistical power while minimizing recruitment costs, participation was limited to mothers, as they are more likely (than fathers) to take the child to see a doctor. ${ }^{21}$ To be eligible, mothers had to have at least 1 child aged 3 months to 12 years; children aged 3 months or younger with fever should be assessed in hospital and home care is not appropriate. ${ }^{22,23}$ A sample size of 800 participants was estimated to ensure $80 \%$ power to detect a statistically significant difference at $\alpha=0.05$, assuming a small effect size of $\mathrm{d}=0.2$ for the main outcome, intention to attend primary care. Previous research by Godinho et $\mathrm{al}^{28}$ identified this size of effect for an intervention designed to increase vaccination intentions.

\section{Analysis}

The data were analyzed with the statistics program IBM SPSS Statistics 25 (International Business Machines Corp) and its extension module, Amos, 
using an alpha level of $P<.05$ for significance tests. Descriptive statistics were calculated for demographic and clinical sample characteristics. Following assignment of numerical scores in the opposite direction for reverse coded survey items, scales were computed by summing items as outlined in Table 1 . Their reliability in the current sample was assessed with Cronbach's $\alpha$ and distributions examined with histograms and Shapiro-Wilk tests. Scales had high internal consistencies (Table 1) and the main outcome variable, attendance intentions, was left-skewed $(\mathrm{S}-\mathrm{W}=0.87$, $P<.001$; skewness $=-0.62, \mathrm{SE}=0.09$ ). Bootstrapping was used for following statistical procedures, drawing multiple samples $(\mathrm{n}=800+)$ randomly from the original sample, to allow for robust inferences despite the nonnormality distribution. ${ }^{47,48}$ Compared with normalizing transformations, bootstrapping has the advantage that measurement units remain unchanged, simplifying output interpretations. ${ }^{49,50}$ Content analysis was used to develop coding frameworks for the open-ended questions, summarizing responses in quantifiable categories. ${ }^{51}$ Two coders (A.S., A.U.), with a background in health psychology and experience in infection research, independently coded responses without knowing participants' experimental allocation, discussing discrepancies to reach agreement. Clinical colleagues were available for further discussion, but as responses were typically short comments instead of detailed elaborations, this was not required. Correspondingly, inter-rater reliabilities were high.

The effect size and CI was calculated comparing the intervention group with the control group. Following assumption tests ( $D W=2.104)$ and dummycoding categorical variables, linear regression analysis was used to test the intervention effect while controlling for demographic and clinical characteristics. The relationship between variables, hypothesized based on prior research and theoretical assumptions concerning the intervention behavior change pathway, was examined specifying a path model. The a priori hypothesis was that the intervention would have an indirect effect (mediated through capability, opportunity, and motivational factors) on intentions to visit primary care for the specified illness scenario. ${ }^{18}$ The model specification ensured the pathway analysis preconditions of model linearity, causal closure, unitary of variables, and a maximum of 1 curved arrow per path. ${ }^{52}$ There were no missing data for model parameters and the sample size of 806 sufficed to calculate valid estimates. The model was assessed by the $\chi^{2}$ test statistic, the Comparative Fit Index (CFI), and the Root mean square error of approximation (RMSEA). Considering that a nonsignificant $\chi^{2}$ value, CFI $>0.90$, and RMSEA $<0.06$ indicate a good fit, ${ }^{53}$ the model, as specified accord- ing to assumed intervention behavior change pathway, was not an acceptable fit for the data $\left(\chi^{2}=320.396\right.$, $\mathrm{df}=12, P<.001 ; \mathrm{CFI}=0.785 ; \mathrm{RMSEA}=0.179)$. To identify a model that better represented the data, post hoc model fitting was carried out by examining the modification indexes that pointed to possible model misspecifications. ${ }^{54}$ The model adjustment significantly improved its fit on both indices (CFI $=0.99$, RMSEA $=0.02)$ and resulted in a significant $\chi^{2}$ test result $\left(\chi^{2}=6.445, \mathrm{df}=5, P=.265\right)$. To assess participants' perception of the material, feedback scales and open-ended questions were examined, and drag and drop responses to the intervention component ratings sorted according to importance, generating a diverging stacked bar chart.

\section{RESULTS}

Of 2,451 individuals responding to the survey invitation, 806 were included in the final sample (32.9\%). Excluded participants either belonged to a sampling quota that was already full $(\mathrm{n}=911)$, dropped out before randomization $(n=341)$, or partway through the survey $(n=363)$, or did not fulfill data quality requirements $(\mathrm{n}=30)$ according to algorithms set to identify straight-liners (choosing only 1 answer option for each question and completing the survey in less than half the median completion time). ${ }^{55}$ Exclusions were carried out by the market research company commissioned to recruit the representative sample (without knowlegde of the research aim and with no interest in the outcome) before the authors conducted the analysis according to the protocol. ${ }^{46}$ A detailed description of participant enrollment and inclusion is given in Supplemental Appendix 4, available at http:// www.AnnFamMed.org/content/17/3/239/suppl/DC1/. Most participants (70\%) were primary caregivers and had attended primary care with their youngest child at least once in the past year (76\%). A minority of participants $(10 \%)$ reported that their child had chronic health issues, most frequently asthma $(n=13)$, allergies $(n=7)$, or eczema $(n=3)$. Table 2 provides an overview of sample demographics and clinical characteristics.

\section{Intervention Effects on Primary Care Attendance Intentions}

Scores on the 2 -item intention to attend primary care scale ranged from 2 to 10 in the sample (possible range 2 to 10). The mean intention to attend score was $7.29(\mathrm{SD}=2.56)$, with the intervention group reporting lower attendance intentions (mean $=6.45$, $\mathrm{SD}=2.57)$ than the control group (mean $=8.12$, $\mathrm{SD}=2.28$ ). The average difference of 1.67 between the intervention and control groups represents a 
medium-sized effect ( $d=0.69,95 \% \mathrm{CI}, 0.55-0.83)$. When divided by 2 to convert back to the original 5 -point scale (strongly disagree to strongly agree) used to rate both intentions to attend items, the

Table 2. Demographic and Clinical Characteristics of the Sample

\begin{tabular}{|c|c|c|c|}
\hline Characteristics & $\begin{array}{c}\text { Total } \\
\text { Sample } \\
(\mathrm{N}=806), \\
\text { No. }(\%)\end{array}$ & $\begin{array}{c}\text { Intervention } \\
\text { Group } \\
\text { (n=403), } \\
\text { No. }(\%)\end{array}$ & $\begin{array}{l}\text { Control Group } \\
(n=403), \\
\text { No. }(\%)\end{array}$ \\
\hline \multicolumn{4}{|l|}{ Mother } \\
\hline \multicolumn{4}{|l|}{ Age, y } \\
\hline $18-29$ & $145(18.0)$ & $74(18.4)$ & $71(17.6)$ \\
\hline $30-39$ & $412(51.1)$ & $208(51.6)$ & $204(50.6)$ \\
\hline $40-65$ & $249(30.9)$ & $121(30.0)$ & $128(31.8)$ \\
\hline \multicolumn{4}{|l|}{ Region } \\
\hline Northern England & $235(29.2)$ & $123(30.5)$ & $112(27.8)$ \\
\hline Southern England & $223(27.7)$ & $115(28.5)$ & $108(26.8)$ \\
\hline Midlands & $139(17.2)$ & $75(18.6)$ & $64(15.9)$ \\
\hline Greater London & $135(16.7)$ & $56(13.9)$ & 79 (19.6) \\
\hline East of England & $74(9.2)$ & $34(8.4)$ & $40(9.9)$ \\
\hline \multicolumn{4}{|l|}{ Employment status } \\
\hline Employed & $578(71.7)$ & $285(70.7)$ & $293(72.7)$ \\
\hline Full-time parent/homemaker & $182(22.6)$ & $93(23.1)$ & $89(22.1)$ \\
\hline Unemployed & $36(4.5)$ & $22(5.5)$ & $14(3.5)$ \\
\hline Student/pupil & $8(1.0)$ & $1(0.2)$ & $7(1.7)$ \\
\hline Retired & $2(0.2)$ & $2(0.5)$ & $0(0.0)$ \\
\hline \multicolumn{4}{|l|}{ Education } \\
\hline No official qualification & $15(1.9)$ & $6(1.5)$ & $9(2.2)$ \\
\hline School-leaving qualification & $387(48)$ & $205(50.9)$ & $182(45.2)$ \\
\hline University qualification & $404(50.1)$ & $192(47.6)$ & $212(52.6)$ \\
\hline \multicolumn{4}{|l|}{ Ethnicity } \\
\hline White & $681(84.5)$ & $347(86.1)$ & $334(82.9)$ \\
\hline Asian & $67(8.3)$ & $31(7.7)$ & $36(8.9)$ \\
\hline Black & $27(3.3)$ & $11(2.7)$ & $16(4.0)$ \\
\hline Mixed & $5(0.6)$ & $10(2.5)$ & $12(3.0)$ \\
\hline Rather not answer & $5(0.6)$ & $2(0.5)$ & $3(0.7)$ \\
\hline Other group & $4(0.5)$ & $2(0.5)$ & $2(0.5)$ \\
\hline \multicolumn{4}{|l|}{ Caregiving role for youngest child } \\
\hline Primary caregiver & $566(70.2)$ & $282(70.0)$ & $284(70.5)$ \\
\hline Shared caregiving role & $240(29.8)$ & $121(30.0)$ & $119(29.5)$ \\
\hline \multicolumn{4}{|l|}{ Youngest child } \\
\hline \multicolumn{4}{|l|}{ Sex } \\
\hline Boy & $388(48.1)$ & $191(47.4)$ & $197(48.9)$ \\
\hline Girl & 418 (51.9) & $212(52.6)$ & $206(51.1)$ \\
\hline \multicolumn{4}{|l|}{ Age, y } \\
\hline $0.25-4$ & $282(35.0)$ & $140(34.7)$ & $142(35.2)$ \\
\hline $5-8$ & $276(34.2)$ & $148(36.7)$ & $128(31.8)$ \\
\hline $9-12$ & $248(30.8)$ & $115(28.5)$ & $133(33.0)$ \\
\hline \multicolumn{4}{|l|}{ Primary care visits in past year } \\
\hline 0 & $191(23.7)$ & $94(23.3)$ & $97(24.1)$ \\
\hline 1 & $250(31.0)$ & $136(33.7)$ & $114(28.3)$ \\
\hline 2 & $185(23.0)$ & $89(22.1)$ & $96(23.8)$ \\
\hline$>3$ & $180(22.3)$ & $84(20.8)$ & $96(23.8)$ \\
\hline \multicolumn{4}{|l|}{ Chronic health issues } \\
\hline No & $724(89.8)$ & $366(90.8)$ & $358(88.8)$ \\
\hline Yes & $82(10.2)$ & $37(9.2)$ & $45(11.2)$ \\
\hline
\end{tabular}

intervention was associated with an almost 1-point decrease $(0.84)$ in attendance intentions.

Consistent with this analysis, participants in the intervention group had lower attendance intentions than those in the control group when adjusting for demographic and clinical characteristics associated with attendance intentions $\left(\mathrm{R}^{2}=0.17\right.$, $\mathrm{F}_{20,785}=8.175, P<.001$; Table 3):

Asian participants had higher intentions and black participants lower intentions than white participants; participants from the greater London area had higher intentions compared with Northern England, and participants with older children had lower intentions than those with younger children. The intervention effect was still significant $\left(f^{2}=0.08\right)$ although small when adjusting for those characteristics, with a difference of 0.04 between the adjusted ( $\mathrm{B}=-1.66,95 \% \mathrm{CI},-1.99$ to -1.32 ) and the unadjusted intervention regression coefficient $(\mathrm{B}=-1.62$, $95 \% \mathrm{CI},-1.97$ to -1.30$)$.

\section{Mediating Effects of Capability, Motivation, and Opportunity}

The a priori hypothesis was that the intervention effect on primary care attendance would be indirect and completely mediated through assessed capability, opportunity, and motivational factors. This model was not an acceptable fit for the data $\left(\chi^{2}=320.396, \mathrm{df}=12, P<.001\right.$, $\mathrm{CFI}=0.79$, RMSEA $=0.18)$. Post hoc model fitting resulted in the adjusted model $\left(\chi^{2}=6.445, \mathrm{df}=5, P=0.265\right.$, $\mathrm{CFI}=0.99$, RMSEA $=0.02$ ) outlined in Figure 1, which accounted for $56.9 \%$ of the variance in primary care attendance intentions. According to the refit model, most of the intervention's effect on attendance intentions $(\mathrm{B}=-0.33, \mathrm{SE}=0.03$; $95 \% \mathrm{CI},-0.40$ to -0.26$)$ was still mediated by participants' capabilities, motivation, and opportunities $(\mathrm{B}=-0.231, \mathrm{SE}=0.025$; $95 \% \mathrm{CI},-0.279$ to -0.180$)$. The intervention specifically increased infection and antibiotic knowledge, 
reduced concerns about symptom severity, and counteracted the perception of attendance as an accepted and expected social norm (Table 4). Those factors were directly associated with lower attendance intentions. Further direct effects included (1) a small but significant negative effect of the intervention on attendance intentions and number of resources consulted, (2) a negative effect of information sufficiency on attendance seen as a social norm, (3) a negative effect of infection and antibiotic knowledge on attendance seen as a social norm but a positive effect on number of mentioned resources, and (4) a negative effect of confidence in home-care capabilities on worries. There was no direct intervention effect on perceived sufficiency of available information or on number or confidence in self-care capabilities.

\section{Feedback on the Intervention Material}

Overall, participants regarded the intervention positively in their open-ended comments, typically highlighting its information as valuable, useful, and useable, eg: "Excellent resource for parents. Really puts people's minds at rest of the signs and symptoms to look out for, and in an easy format to find the exact information you are looking for." Ratings of intervention components (Figure 2) highlighted that information about primary care attendance and symptoms were perceived to be most important, and information on locally circulating viruses was the least important.

Participants positively assessed the intervention's content and presentation, rating the intervention materials to be generally clear (median $=30$, range 5 to 35 , interquartile range (IQR) is $9=34-29)$, credible (median $=17$, range 3 to $21, \mathrm{IQR}$ is $7=20-13)$, cognitively challenging and stimulating (median $=25$, range 5 to 35 , IQR is $8=29-21$ ), novel (median $=12$, range 3 to $21, \mathrm{IQR}$ is $3=14-11$ ), and emotionally arousing (median $=33$, range 7 to 49 , IQR is $10=38-28)$. Two participants voiced concerns for the child's safety if not seen by a doctor and thought the intervention was "irresponsible" for deterring attendance.

\section{DISCUSSION}

The parent-targeted online intervention, combining real-time information on locally circulating RTIs with symptom information and advice, was associated with lower intentions to attend primary care for a child with a hypothetical RTI. The intervention effect on intentions was mostly indirect and mediated by increased infection and antibiotic knowledge, reduced symptom severity concerns, and less perceived social pressure to attend. The intervention material was generally well received, particularly the information about when to attend primary care, and symptoms.

\section{Strengths and Limitations}

The current research was a theoryinformed experimental evaluation of a novel, evidence-based intervention. Such initial intervention tests 


\section{Table 4. Bootstrapped Effects of the Intervention on Mediating Factors and Primary Care Attendance Intentions}

\begin{tabular}{|c|c|c|c|}
\hline Intervention Effects & B $(95 \% \mathrm{Cl})$ & SE & $P$ Value \\
\hline \multicolumn{4}{|l|}{ Direct effects } \\
\hline Infection and antibiotic knowledge & $0.18(0.12$ to 0.24$)$ & 0.03 & $.002^{\mathrm{a}}$ \\
\hline Worry/perceived severity & $-0.14(-0.20$ to -0.08$)$ & 0.03 & $.002^{\mathrm{a}}$ \\
\hline Social norms concerning primary care attendance & $-0.23(-0.30$ to -0.17$)$ & 0.03 & $.002^{\mathrm{a}}$ \\
\hline Number of mentioned resources & $-0.13(-0.19$ to -0.06$)$ & 0.03 & $.002^{\mathrm{a}}$ \\
\hline Primary care attendance intentions & $-0.09(-0.14$ to -0.04$)$ & 0.03 & $.003^{a}$ \\
\hline \multicolumn{4}{|l|}{ Indirect effects } \\
\hline Confidence in home-care capabilities & $0.04(0.01$ to 0.07$)$ & 0.02 & $.008^{\mathrm{a}}$ \\
\hline Worry/perceived severity & $-0.15(-0.19$ to -0.11$)$ & 0.02 & $.002^{\mathrm{a}}$ \\
\hline Social norms concerning primary care attendance & $-0.02(-0.04$ to -0.01$)$ & 0.01 & $.003^{\mathrm{a}}$ \\
\hline Number of mentioned resources & $0.03(0.02$ to 0.05$)$ & 0.01 & $.001^{\mathrm{b}}$ \\
\hline Primary care attendance intentions & $-0.23(-0.28$ to -0.18$)$ & 0.03 & $.002^{\mathrm{a}}$ \\
\hline \multicolumn{4}{|l|}{$\mathrm{B}=$ regression coefficient; $\mathrm{SE}=$ standard error. } \\
\hline \multicolumn{4}{|l|}{ a $P \leq .01$} \\
\hline
\end{tabular}

thetical scenarios may, however, show different results.

The survey itself was designed to assess all constructs hypothesized to affect attendance intentions. Ease of readability was average, and the survey was tested before data collection by a parent advisory group for understandability and burdensomeness. That some participants would find the survey too lengthy or struggle to understand the intervention material or survey questions cannot be ruled out, especially for those with different sociodemographic profiles than the mostly white, educated parent advisory group members. Furthermore, and agile development approaches are important when developing electronic health interventions particularly for complex interventions that promise considerable improvements of current practice, but require substantial financial investments. ${ }^{28,56}$ Considering behavioral science theory for the intervention development and the research design, advances the growing field of Internet-based behavior change interventions, which often lack sound theoretical grounding. ${ }^{57}$

Using intentions as a proxy-measure of behavior and a hypothetical illness scenario instead of examining responses to real illness episodes is a potential limitation of this study and should be considered when interpreting the findings. Evidence from a metaanalysis suggests that intentions are likely to be good predictors for single action, specific, nonhabitual behaviors, such as primary care attendance. ${ }^{58}$ Outcomes in response to real-life illnesses instead of hypo- by limiting the current research to English mothers, we are unable to say if the intervention would be as effective for reducing intentions to attend primary care among fathers or in other countries. The quota sampling approach ensured a representative but nonrandom sample of English mothers. The re-specification of the original path model was exploratory in nature. ${ }^{52}$

\section{Relation to Prior Research}

The intervention had an effect on factors shown to be important influences on parents' decisions to consult primary care for pediatric RTIs, ${ }_{1}^{13,14,59,60}$ and was associated with reduced primary care attendance intentions. The intervention increased, for example, knowledge of infections and antibiotic usage, which is important as widespread misperceptions about antibiotic use still exist. ${ }^{21,61}$ The observed attendance intention patterns correspond with research on parents' RTI consulation

Figure 2. Information components included in the intervention rated by perceived importance.

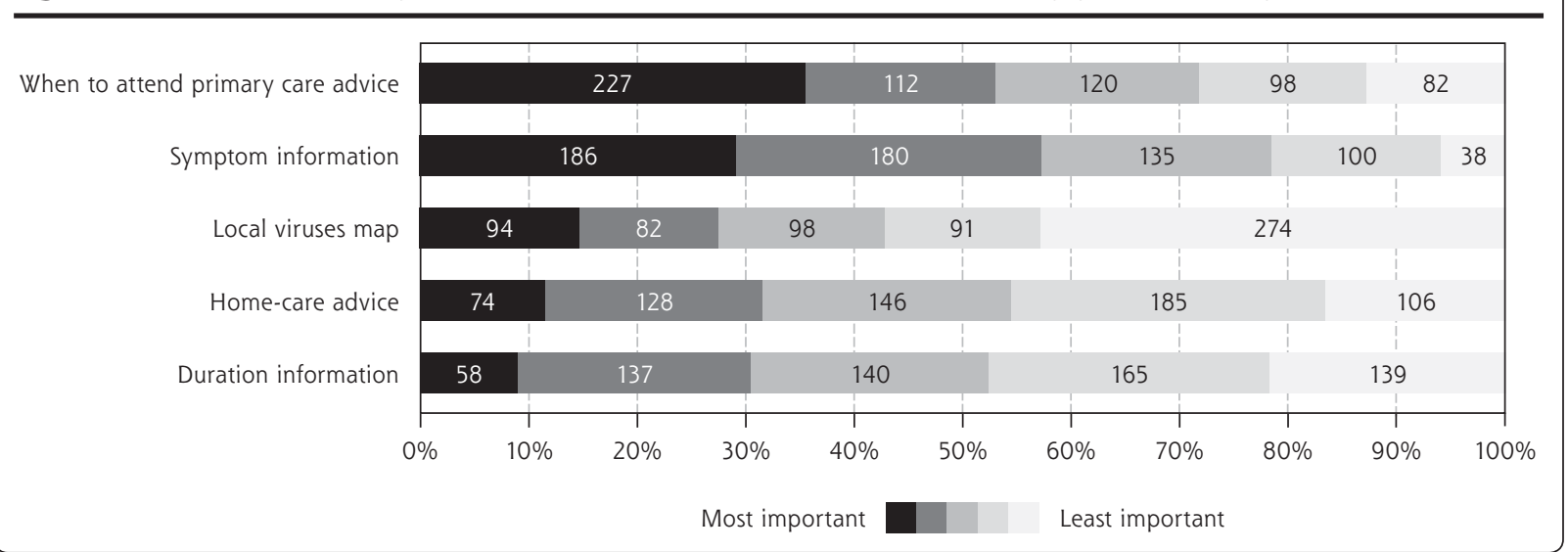


behavior that found non-white ethnicities will consult more often. ${ }^{62}$ The evidence is not conclusive, but could be due to a combination of different cultural practices and higher anxiety levels, for example, from operating in a second language and in unfamiliar contexts in the case of migrant communities. Parents who are part of minority or discriminated-against groups may feel more pressure to consult, to avoid accusations of failing to attend when necessary and of neglect. ${ }^{14,63}$

As a whole, the intervention was well received and the information provided was rated as credible, cognitively stimulating, and emotionally engaging. This is an important finding, given that electronic health research has found that ease of use, understanding, credibility, and visual appeal are important factors for encouraging intervention engagement. ${ }^{64-66}$ The positive assessments of the intervention's usefulness is supported by prior qualitative research suggesting that parents were interested in accessing information online about locally prevalent RTIs, symptoms, and home-care strategies, before consulting primary care to inform lay diagnoses and make consulation decisions..$^{15}$ The information would be particularly helpful for first-time parents and parents of young children. Some parents were interested in regularly checking the website to monitor circulating viruses. The intervention could also be used in an effort to prevent infections by heightening awareness of circulating viruses, and increasing the promotion of hand hygiene and other infection-prevention techniques. Accessing the information with primary care clinicians during consultations was also seen as acceptable and could help publicize the intervention.

A key finding was that the novel intervention component, providing information on locally circulating viruses, was seen as less important by participants than symptom and home-care information. It might be useful to add further details on how to interpret and use the dynamic surveillance information, especially for consultation decision making. The static information components, preferred by participants, more directly addressed factors previously identified as influencing consultation behavior. ${ }^{14}$ This study provides evidence that interventions including such information can change primary care attendance intentions. Ultimately, what users like and engage with is not necessarily linked to the effectiveness of the intervention components in changing behaviors. ${ }^{67}$ The effects of individual intervention components and their interactions remain to be determined.

\section{Impact and Future Research}

Increasing smartphone use means that web-based resources are accessible to people from all socioeconomic backgrounds, and they are particularly suited for interventions that have dynamic elements requiring frequent updates. Paper-based versions of such interventions would be less practical. Even a small size effect of the intervention on parents' attendance behavior would be impactful if the intervention was rolled out widely, as pediatric RTIs are one of the main reasons for primary care consultations with children. ${ }^{1}$ Future research should evaluate intervention effects on observed behavioral outcomes in real-world settings, and also examine long-term effects and cost effectiveness. As the current online study was limited to participants with Internet access, the impact of Internet use proficiency should be examined. ${ }^{28}$ Factorial experimental design studies could help to untangle the complex network of relationships observed between intervention components, mediating factors, and primary care attendance to further refine the intervention. ${ }^{68,69}$ Since the intervention was effective in increasing knowledge and reducing concerns in mothers, similar interventions aimed at other audiences such as school personnel and clinicians could also be developed to improve the care for pediatric RTIs. Expanding the application of the intervention to other contexts, target groups, and countries requires a careful analysis of the specific setting, appropriate adaptions, and further testing, as effective behavior change is highly context and target-group specific. ${ }^{18}$

\section{CONCLUSION}

The theory- and evidence-based online intervention was effective at reducing primary care attendance intentions for self-limiting, pediatric RTIs. Information on locally circulating viruses, a novel intervention component, was rated as being less important compared with information on when to attend primary care and on symptoms and their management. The effectiveness of individual intervention components in changing parents' behavior requires further research.

To read or post commentaries in response to this article, see it online at http://www.AnnFamMed.org/content/17/3/239.

Key words: antimicrobial resistance; behavioral medicine; child health; eHealth; primary care

Submitted September 1, 2018; submitted, revised, January 21, 2019; accepted February 12, 2019.

Funding support: This research is supported by the National Institute for Health Research, Health Protection Research Unit in Evaluation of Interventions at the University of Bristol, in partnership with Public Health England. The views expressed are those of the authors and not necessarily those of the National Health Service, the NIHR, the Department of Health and Social Care or Public Health England. Joanna Kesten is partly funded by NIHR HPRU in Evaluation of Interventions at the University of Bristol in partnership with Public Health England and NIHR Collaboration for Leadership in Applied Health Research and Care West at University Hospitals Bristol NHS Foundation Trust. 
Prior presentations: Portions of this study have been presented as a poster at the South West Regional Conference of the Society for Academic Primary Care held March 23-24, 2017; Oxford, UK, and as a paper at the PHE Research and Applied Epidemiology Scientific Conference held March 21-22, 2017; Coventry, UK, and at the $3^{\text {rd }}$ Digital Behavior Change Conference held February 22-23, 2017; London, UK.

Acknowledgments: The authors wish to thank Arpita Upadhyaya for her help double-coding of the open-ended survey answers.

Supplementary materials: Available at http://www.AnnFamMed. org/content/17/3/239/suppl/DC1/.

\section{References}

1. Hay AD, Heron J, Ness A; ALSPAC study team. The prevalence of symptoms and consultations in pre-school children in the Avon Longitudinal Study of Parents and Children (ALSPAC): a prospective cohort study. Fam Pract. 2005;22(4):367-374.

2. Hobbs FDR, Bankhead C, Mukhtar T, et al; National Institute for Health Research School for Primary Care Research. Clinical workload in UK primary care: a retrospective analysis of 100 million consultations in England, 2007-14. Lancet. 2016;387(10035):2323-2330.

3. Hollinghurst S, Gorst C, Fahey T, Hay AD. Measuring the financial burden of acute cough in pre-school children: a cost of illness study. BMC Fam Pract. 2008;9:10.

4. Ashworth M, Charlton J, Ballard K, Latinovic R, Gulliford M. Variations in antibiotic prescribing and consultation rates for acute respiratory infection in UK general practices 1995-2000. Br J Gen Pract. 2005;55(517):603-608.

5. McNulty CAM, Nichols T, French DP, Joshi P, Butler CC. Expectations for consultations and antibiotics for respiratory tract infection in primary care: the RTI clinical iceberg. Br J Gen Pract. 2013; 63(612):e429-e436.

6. Domin MA. Highly virulent pathogens-a post antibiotic era? $\mathrm{Br}$ J Theatre Nurs. 1998;8(2):14-18.

7. Fishman N. Antimicrobial stewardship. Am J Infect Control. 2006; 34(5)(Suppl 1):S55-S63, discussion S64-S73.

8. Laxminarayan R, Duse A, Wattal C, et al. Antibiotic resistance-the need for global solutions. Lancet Infect Dis. 2013;13(12):1057-1098.

9. O'Neill J. Antimicrobial Resistance : tackling a crisis for the health and wealth of nations. Review on Antimicrobial Resistance. 2014:1-16.

10. Andrews T, Thompson M, Buckley DI, et al. Interventions to influence consulting and antibiotic use for acute respiratory tract infections in children: a systematic review and meta-analysis. PLoS One. 2012;7(1):e30334.

11. Doron S, Davidson LE. Antimicrobial stewardship. Mayo Clin Proc. 2011;86(11):1113-1123.

12. Magsarili HK, Girotto JE, Bennett NJ, Nicolau DP. Making a case for pediatric antimicrobial stewardship programs. Pharmacotherapy. 2015;35(11):1026-1036.

13. Ingram J, Cabral C, Hay AD, Lucas PJ, Horwood J; TARGET team. Parents' information needs, self-efficacy and influences on consulting for childhood respiratory tract infections: a qualitative study. BMC Fam Pract. 2013;14(1):106.

14. Cabral C, Lucas PJ, Ingram J, Hay AD, Horwood J. "It's safer to ..." parent consulting and clinician antibiotic prescribing decisions for children with respiratory tract infections: An analysis across four qualitative studies. Soc Sci Med. 2015;136-137:156-164.

15. Kesten JM, Anderson EC, Lane I, Hay AD, Cabral C. Parent views on the content and potential impact of respiratory tract infection surveillance information: semistructured interviews to inform future research. BMJ Paediatr Open. 2017;1(1):e000036.
16. Craig P, Dieppe P, Macintyre $S$, et al. Developing and evaluating complex interventions: new guidance. British Medical Journal. 2008; 337:a1655.

17. Michie S, West R. Guide to Development and Evaluation of Digit Behaviour Change Interventions in Healthcare. Sutton, UK: Silverback Publishing; 2016.

18. Michie S, van Stralen MM, West R. The behaviour change wheel: a new method for characterising and designing behaviour change interventions. Implement Sci. 2011;6(1):42.

19. Abraham C, Michie S. A taxonomy of behavior change techniques used in interventions. Health Psychol. 2008;27(3):379-387.

20. Public Health England. PHE Weekly National Influenza Report. London, UK: Public Health England; 2016.

21. Cabral C, Ingram J, Lucas PJ, et al. Influence of clinical communication on parents' antibiotic expectations for children with respiratory tract infections. Ann Fam Med. 2016;14(2):141-147.

22. NICE. Fever in Under 5s: Assessment and Initial Management: Clinical Guideline. London, UK: NICE; 2013.

23. NICE. Traffic Light System for Identifying Risk of Serious Illness. London, UK: Nice; 2013.

24. Cassell MM, Jackson C, Cheuvront B. Health communication on the Internet: an effective channel for health behavior change? J Health Commun. 1998;3(1):71-79.

25. Kessels RPC. Patients' memory for medical information. J R Soc Med. 2003;96(5):219-222.

26. Kreuter MW, Wray RJ. Tailored and targeted health communication: strategies for enhancing information relevance. Am J Health Behav. 2003;27(3)(Suppl 3):S227-S232.

27. Stephens KK, Rains SA. Information and communication technology sequences and message repetition in interpersonal interaction. Communic Res. 2011;38(1):101-122.

28. Glasgow RE. eHealth evaluation and dissemination research. Am J Prev Med. 2007;32(5)(Suppl):S119-S126.

29. Godinho CA, Yardley L, Marcu A, Mowbray F, Beard E, Michie S. Increasing the intent to receive a pandemic influenza vaccination: Testing the impact of theory-based messages. Prev Med. 2016;89: 104-111.

30. McGlone MS, Bell RA, Zaitchik ST, McGlynn J III. Don't let the flu catch you: agency assignment in printed educational materials about the H1N1 influenza virus. J Health Commun. 2013;18(6): 740-756.

31. Ajzen I. Constructing a theory of planned behavior questionnaire. Biofeedback Self Regul. 2010;17:1-7.

32. Armitage CJ. Efficacy of a brief worksite intervention to reduce smoking: the roles of behavioral and implementation intentions. J Occup Health Psychol. 2007;12(4):376-390.

33. Jackson C, Lawton R, Knapp P, et al. Beyond intention: do specific plans increase health behaviours in patients in primary care? A study of fruit and vegetable consumption. Soc Sci Med. 2005; 60(10):2383-2391.

34. Payaprom Y, Bennett P, Alabaster E, Tantipong H. Using the Health Action Process Approach and implementation intentions to increase flu vaccine uptake in high risk Thai individuals: a controlled beforeafter trial. Health Psychol. 2011;30(4):492-500.

35. Tickner S, Leman PJ, Woodcock A. The Immunisation Beliefs and Intentions Measure (IBIM): predicting parents' intentions to immunise preschool children. Vaccine. 2010;28(19):3350-3362.

36. Witte K, Cameron KA, M CKeon JK, Berkowitz JM. Predicting risk behaviors: development and validation of a diagnostic scale. J Health Commun. 1996;1(4):317-341.

37. Griffin RJ, Neuwirth K, Dunwoody S, Giese J. Information sufficiency and risk communication. Media Psychol. 2004;6(1):23-61. 
38. Rubin GJ, Potts HWW, Michie $S$. The impact of communications about swine flu (influenza A H1N1v) on public responses to the outbreak: results from 36 national telephone surveys in the UK. Health Technol Assess. 2010;14(34):183-266.

39. Purssell E, While A. Development of a scale to measure parental self-efficacy in the care of pre-school children during periods of health and minor illness: integrating health and social policy methods. J Clin Nurs. 2011;20(11-12):1623-1631.

40. Huang SS, Rifas-Shiman SL, Kleinman K, et al. Parental knowledge about antibiotic use: results of a cluster-randomized, multicommunity intervention. Pediatrics. 2007;119(4):698-706.

41. Kuzujanakis M, Kleinman K, Rifas-Shiman S, Finkelstein JA. Correlates of parental antibiotic knowledge, demand, and reported use. Ambul Pediatr. 2003;3(4):203-210.

42. Lee GM, Friedman JF, Ross-Degnan D, et al. Misconceptions about colds and predictors of health service utilization. Pediatrics. 2003; 111(2):231-236.

43. Lane DR, Harrington NG, Donohew L, Zimmerman RS. Dimensions and validation of a perceived message cognition value scale. Commun Res Rep. 2006;23(3):149-161.

44. Palmgreen P, Stephenson MT, Everett MW, Baseheart JR, Francies $R$. Perceived message sensation value (PMSV) and the dimensions and validation of a PMSV scale. Health Commun. 2002;14(4): 403-428.

45. Ley P, Florio T. The use of readability formulas in health care. Psychol Health Med. 1996;1(1):7-28.

46. Schneider A, Cabral C, Herd N, et al. Reducing Primary Care Visits Using Real Time Paediatric Respiratory Tract Infection Surveillance Data: An Experimental Study of a Parent- Targeted Intervention - Study Protocol. London, UK: Open Science Framework; 2017.

47. Banjanovic ES, Osborne JW. Confidence intervals for effect sizes: applying bootstrap resampling. Pract Assess, Res Eval. 2016;21(5): $1-20$.

48. Shrout PE, Bolger N. Mediation in experimental and nonexperimental studies: new procedures and recommendations. Psychol Methods. 2002;7(4):422-445.

49. Fox J. Applied Regression Analysis and Generalized Linear Models. 3rd ed. Los Angeles, CA: SAGE Publications; 2016.

50. Freedman DA. Bootstrapping regression models. Ann Stat. 1981; 9(6):1218-1228.

51. Miles MB, Huberman AM. Qualitative Data Analysis: An Expanded Sourcebook. 2nd ed. Thousand Oaks: Sage Publications; 1994.

52. Neale MC, Cardon LR. Path analysis and structural equations. In Methodology for Genetic Studies of Twins and Families. Dordrecht, Netherlands: Springer; 1992.

53. Li-tze Hu L. Bentler PM. Cutoff criteria for fit indexes in covariance structure analysis: conventional criteria versus new alternatives. Struct Equ Modeling. 1999;6(1):1-55.

54. Byrne BM. Structural Equation Modeling With AMOS: Basic Concepts, Applications, and Programming. 3rd ed. New York, NY: Routledge; 2016.

55. Zhang C, Conrad F. Speeding in web surveys: the tendency to answer very fast and its association with straightlining. Surv Res Methods. 2014;8(2):127-135.
56. Mohr DC, Schueller SM, Riley WT, et al. Trials of intervention principles: evaluation methods for evolving behavioral intervention technologies. J Med Internet Res. 2015;17(7):e166.

57. Webb TL, Joseph J, Yardley L, Michie S. Using the internet to promote health behavior change: a systematic review and metaanalysis of the impact of theoretical basis, use of behavior change techniques, and mode of delivery on efficacy. J Med Internet Res. 2010;12(1):e4.

58. Sheeran P. Intention-behavior relations: a conceptual and empirical review. Eur Rev Soc Psychol. 2002;12(1):1-36.

59. Cabral C, Ingram J, Hay AD, Horwood J; TARGET team. "They just say everything's a virus"-parent's judgment of the credibility of clinician communication in primary care consultations for respiratory tract infections in children: a qualitative study. Patient Educ Couns. 2014;95(2):248-253.

60. Lucas PJ, Cabral C, Hay AD, Horwood J. A systematic review of parent and clinician views and perceptions that influence prescribing decisions in relation to acute childhood infections in primary care. Scand J Prim Health Care. 2015;33(1):11-20.

61. Zhu YG, Gillings $M$, Simonet P, Stekel D, Banwart S, Penuelas J. Microbial mass movements. Science. 2017;357(6356):1099-1100.

62. de Jong BM, van der Ent CK, van Putte Katier N, et al; WHISTLER Study Group. Determinants of health care utilization for respiratory symptoms in the first year of life. Med Care. 2007;45(8):746-752.

63. Neill SJ, Jones $\mathrm{CH}$, Lakhanpaul M, Roland DT, Thompson MJ. Parents' help-seeking behaviours during acute childhood illness at home: a contribution to explanatory theory. J Child Health Care. 2016;20(1):77-86

64. Garnett C, Crane D, West R, Brown J, Michie S. Identification of behavior change techniques and engagement strategies to design a smartphone app to reduce alcohol consumption using a formal consensus method. JMIR Mhealth Uhealth. 2015;3(2):e73.

65. Perski $O$, Blandford $A$, West $R$, Michie $S$. Conceptualising engagement with digital behaviour change interventions: a systematic review using principles from critical interpretive synthesis. Transl Behav Med. 2017;7(2):254-267.

66. Ubhi HK, Michie $S$, Kotz D, et al. Characterising smoking cessation smartphone applications in terms of behaviour change techniques, engagement and ease-of-use features. Transl Behav Med. 2016;6(3): 410-417.

67. Heffner JL, Vilardaga R, Mercer LD, Kientz JA, Bricker JB. Featurelevel analysis of a novel smartphone application for smoking cessation. Am J Drug Alcohol Abuse. 2015;41(1):68-73.

68. McMahon SK, Lewis B, Oakes JM, Wyman JF, Guan W, Rothman AJ. Assessing the effects of interpersonal and intrapersonal behavior change strategies on physical activity in older adults: a factorial experiment. Ann Behav Med. 2017;51(3):376-390.

69. van Genugten L, Dusseldorp E, Webb TL, van Empelen P. Which combinations of techniques and modes of delivery in internet-based interventions effectively change health behavior? A meta-analysis. J Med Internet Res. 2016;18(6):e155. 